\title{
The Heart and Great Vessels
}

\author{
Ekene Onwuka, ${ }^{1,2}$ Nakesha King, ${ }^{1,2}$ Eric Heuer, ${ }^{1}$ and Christopher Breuer ${ }^{1,2,3}$ \\ ${ }^{1}$ Tissue Engineering and Surgical Research, The Research Institute at Nationwide Children's Hospital, \\ Columbus, Ohio 43205 \\ ${ }^{2}$ College of Medicine, The Ohio State University, Columbus, Ohio 43210 \\ ${ }^{3}$ Department of Pediatric Surgery, Nationwide Children's Hospital, Columbus, Ohio 43205 \\ Correspondence: christopher.breuer@nationwidechildrens.org
}

Cardiovascular disease is the leading cause of mortality worldwide. We have made large strides over the past few decades in management, but definitive therapeutic options to address this health-care burden are still limited. Given the ever-increasing need, much effort has been spent creating engineered tissue to replaced diseased tissue. This article gives a general overview of this work as it pertains to the development of great vessels, myocardium, and heart valves. In each area, we focus on currently studied methods, limitations, and areas for future study.

C ardiovascular disease (CVD) is the leading cause of mortality worldwide associated with more than 17.5 million deaths per year (World Health Organization, www.who .int/cardiovascular_diseases/en). In particular, congenital heart defects are diagnosed in approximately $1 \%$ of live births, making CVD the most common congenital malformation of newborns. Despite the prevalence of heart disease and therapeutic advances over the past 30 years, definitive therapeutic options to address this health-care burden are limited. Here we will discuss the application of tissue engineering to construct functional cardiovascular tissue from a combination of biomaterial and cell types. We will begin by detailing recognized anatomy and transition to the method by which tissue engineering is used to mimic form and function.

\section{FUNCTION, STRUCTURE, AND HISTOLOGY}

\section{Anatomy}

The heart functions as a highly organized physiological pump composed of three layers: the inner endocardium, the thick myocardium, and the outer epicardium. The muscular myocardium generates the force needed to move blood with each contraction. The endocardium is lined by endothelial cells (ECs) that maintain a nonthrombogenic surface, and the epicardium serves as an additional fatty and connective tissue layer between the heart and the serous visceral pericardium.

The four-chambered heart includes two atria and two ventricles. The right atrium receives deoxygenated blood from the body by way of the inferior vena cava (IVC) and superior vena cava (SVC) and delivers it to the right ventricle,

Editor: Joseph P. Vacanti

Additional Perspectives on Tissue Engineering and Regenerative Medicine available at www.perspectivesinmedicine.org

Copyright (C) 2018 Cold Spring Harbor Laboratory Press; all rights reserved; doi: 10.1101/cshperspect.a031922

Cite this article as Cold Spring Harb Perspect Med 2018;8:a031922 


\section{E. Onwuka et al.}

which pumps it through the pulmonary artery to the lungs to be oxygenated. The left atrium then receives the oxygenated blood from the lungs by way of the pulmonary vein and delivers it to the left ventricle, which pumps it through the aorta to supply the metabolic needs of the body. Located at the junction of the right atrium and SVC is the sinoatrial node, which spontaneously generates action potentials that propagate throughout the heart, generating a synchronous contraction.

Unidirectional flow through the heart is maintained by the tricuspid valve between the right atrium and ventricle, the mitral valve between the left atrium and ventricle, and the pulmonary and aortic valves located at the right and left ventricular outflow tracts, respectively. Grossly, the semilunar pulmonary and aortic heart valves are composed of three thin cusps that open easily when exposed to the forward blood flow of ventricular systole, and then rapidly close under the minimal reverse flow of diastole (Schoen 2011). Despite the force applied to the leaflets during diastole, prolapse is prevented by substantial coaptation of the cusps in a crescent-shaped region of the cusp termed the lunula.

\section{Histology}

The myocardium is composed mostly of cardiomyocytes. Cardiomyocytes comprise $80 \%-$ $90 \%$ of the heart volume and are aligned and electrically coupled to surrounding cardiomyocytes. Supporting cell types, including endothelial and smooth muscle cells, organize themselves into a vascular network supplying nutrients to the cardiomyocytes, whereas fibroblasts generate a collagen-dense matrix.

Microscopically, the semilunar heart valve is composed of three layers: the ventricularis, spongiosa, and fibrosa. The fibrosa, which is exposed to the aortic lumen, is composed of primarily collagen fibers that are densely packed parallel to the cuspal free edge and provide most of the mechanical strength of the valve (Cole et al. 1984). The ventricularis layer faces the ventricle and is composed of collagen and radially aligned elastin fibers. Elastin forms an encompassing matrix that binds the collagen fibrous bundles throughout the heart valve, thereby creating an elastin-collagen hybrid network that provides greater mechanical strength (Scott and Vesely 1995). The centrally located spongiosa is composed of glycosaminoglycans (GAGs) and loose collagen fibers. The GAG side chains of proteoglycans make a gelatinous substance to which other supportive extracellular matrix (ECM) molecules can form covalent cross-links (Flanagan and Pandit 2003).

The two most prevalent cell types in heart valves are valvular endothelial cells (VECs) and valvular interstitial cells (VICs). VECs line the surface of valve cusps. They provide a nonthrombogenic blood-tissue interface, maintain a semipermeable membrane that regulates the transfer of large and small molecules through the vascular wall (Rabkin-Aikawa et al. 2005), and play a critical role in the control of inflammatory and immune reactions (Schoen 2008). VICs are primarily responsible for the synthesis and remodeling of valve ECM, maintaining the appropriate structural and functional relationship needed for long-term heart valve competence. This is essential given the constant, rigorous mechanical movement of valves that results in persistent low-level valvular damage necessitating repair.

The great vessels carry blood to and from the heart and include the aorta, IVC, SVC, and pulmonary artery and vein. Blood vessels have three concentric layers: the innermost intima, the media, and the adventitia. The inti$\mathrm{ma}$ is composed of a single layer of luminal squamous ECs attached to the basement membrane. The ECs are in direct contact with flowing blood and form a smooth, antithrombogenic surface. Underlying the endothelium is the subendothelial connective tissue, which is thrombogenic and critical to platelet adhesion, the coagulation cascade, and prevention of hemorrhage during injury (Sarkar et al. 2007). The media is muscular layers of the vessel and is thicker in arteries because of the higher levels of elastin and smooth muscle needed for the propulsion of blood to the body. Last, the adventitia is the outermost connective tissue covering of the vessel. 


\section{DISEASE, TREATMENT, AND CURRENT LIMITATIONS}

\section{Pathophysiology}

The most common cardiovascular pathology is ischemic heart disease, which occurs when a portion of the heart is not appropriately oxygenated, usually because of compromise of the coronary arteries that supply the heart. Coronary artery disease (CAD) is most often caused by atherosclerosis or an accumulation of fatty plaques within the vessel wall that narrows the blood vessel lumen and decreases the amount of blood received by the target. Decreasing blood flow, and therefore oxygen delivery, below a certain threshold leads to angina characterized by reversible discomfort or feeling of chest pressure. Complete occlusion of the artery leads to myocardial infarction (MI), which is associated with a typical pathological progression. Irreversible cell damage occurs within 20-40 min following occlusion (Kumar et al. 2010). Coagulative necrosis begins after $30 \mathrm{~min}$, followed by a robust inflammatory response $24 \mathrm{~h}$ postinfarction that continues for 2 to 3 days. Macrophages ultimately dominate the infarcted zone by 5 to 7 days postinfarction and are responsible for removing dead cells and creating granulation tissue. Weeks to months after the infarction, collagen deposition dominates, and a fibrous scar is formed that reduces the contractile function of the heart and may lead to heart failure (Kumar et al. 2010).

The pathology of heart valve disease manifests itself in two ways. The first, stenosis, results in reduction of forward flow. The second, regurgitation, causes retrograde flow during diastole because of the inability of a valve to completely close. Aortic stenosis, when severe, presents as dyspnea on exertion, chest pain, and syncope. The most frequent cause of aortic stenosis is dystrophic calcification of the aortic valve cusps and annulus. Overall, prevalence of aortic stenosis is $2 \%$, and the incidence of disease is progressively increasing as the American population ages. Mitral valve prolapse, a displacement of valve leaflets into the left atrium during systole, is the most common indication for surgical repair or replacement of this valve. It is most commonly caused by myxomatous degeneration and is often seen in patients with Marfan syndrome, a connective tissue disorder, and can lead to valve incompetence and regurgitation (Kumar et al. 2010). Dysfunction of the tricuspid and pulmonary valves is usually a result of a congenital heart defect. Approximately 20,000 infants are born in the United States each year with a congenital heart malformation, many of which are associated with absence or malformation of the pulmonary valve or artery (Sales et al. 2010). Major congenital heart diseases of the right ventricular outflow tract include truncus arteriosus, pulmonary atresia with ventricular septal defect, Tetralogy of Fallot, transposition of the great vessels with ventricular septal defect and pulmonary atresia, and double-outlet right ventricle.

\section{Current Treatment and Limitations}

One of the key limitations to treating CVD is the lack of tissue regeneration after myocardial injury. Most therapies for acute disease are directed at immediate restoration of vascularization to decrease the amount of damage inflicted by the ischemic event. Coronary angioplasty involves reopening diseased vessels using a balloon or stent apparatus, whereas coronary artery bypass grafting (CABG) surgery involves rerouting blood past diseased segments of coronary arteries to revascularize the cardiac tissue supplied by the affected vessels. The saphenous vein and internal mammary artery are frequently used as conduits for CABGs, but these vessels may also be affected by atherosclerotic disease and are prone to stenosis because of a progressive thickening of the vessel wall known as neointimal hyperplasia. Once a significant amount of myocardium has sustained permanent damage, the majority of existing therapies aim to mitigate the progression to heart failure.

Standard treatment for end-stage valvular dysfunction is heart valve replacement. Prosthetic heart valves are either mechanical and composed entirely of synthetic material or bioprosthetic and fashioned from biological components. Approximately 50\% of implanted 
E. Onwuka et al.

valves in the United States are mechanical, whereas the remainder are bioprosthetic (Pibarot and Dumesnil 2009). Neither material possesses growth potential and are, therefore, not optimal for the pediatric population (Hammermeister et al. 2000). The mechanical heart valve has excellent durability but is associated with a substantial risk of thromboembolism and thrombotic occlusion because of the lack of an endothelial lining and the flow abnormalities that result from a rigid outflow structure (Rahimtoola 2003, 2010). To minimize this risk, chronic anticoagulation therapy is required for all mechanical valve recipients, but systemic anticoagulation renders patients vulnerable to hemorrhagic complications. The combined risk of thromboembolic complications and hemorrhage secondary to anticoagulation constitute the principal disadvantages of mechanical prosthetic valves (Cannegieter et al. 1994).

Bioprosthetic valve replacements, such as glutaraldehyde-fixed xenografts and allografts, are associated with a lower risk of thrombosis and hemolysis than mechanical heart valves (Hammermeister et al. 2000). Patients with glutaraldehyde-fixed xenograft valves do not require therapeutic anticoagulation, but, because they are composed of biologic material, they are prone to structural deterioration. Glutaraldehyde fixation of xenografts causes cross-linking of extracellular matrix collagen subunits that shields antigens and decreases immunogenicity. However, there is increasing evidence that these valves still elicit a significant immune response that leads to calcification and progressive damage (Manji et al. 2012). The structural deterioration eventually results in stenosis or regurgitation and is strongly age-dependent, affecting individuals under 35 years of age more commonly. Nearly uniform failure occurs after 5 years in patients of this age group, but $8 \%-27 \%$ fail after 20 years in those older than 65 years of age (Mykén and Bech-Hansen 2009). The higher rates of failure may be attributed to a more robust immune inflammatory response and metabolism observed in younger individuals (Manji et al. 2012).

\section{THE APPLICATION OF TISSUE ENGINEERING TOWARD THE TREATMENT OF CARDIOVASCULAR DISEASE}

\section{Tissue-Engineering Theory}

The central paradigm underlying tissue engineering involves combining cells with a platform matrix to create neotissue (Langer and Vacanti 1993). The matrix acts as a threedimensional scaffold until proliferating cells produce sufficient ECM to support the organ's structure (Rabkin-Aikawa et al. 2005). Cells can either be cultured on the scaffold in vitro or seeded on the scaffold before implantation of the graft. If cells are to be cultured in vitro, this usually involves placement of the graft into a bioreactor that is used to mimic the physiologic conditions in which the target organ usually resides. Once implanted, the scaffold degrades as cellular proliferation and neotissue formation increases, leaving a living functional organ with growth capacity.

\section{GREAT VESSELS}

An ideal tissue-engineered vascular graft (TEVG) is an antithrombotic, nonimmunogenic, endothelialized structure with durable biomechanical properties akin to those of native vessels (Li and Henry 2011). Additionally, the grafts should have growth capacity, making them an ideal conduit for use in pediatric patients with congenital heart defects. The two recognized techniques for TEVG fabrication are scaffoldguided and self-assembled cell-sheet-based engineering. In this section, we give an overview of these two scaffold techniques as well as current limitations and future direction of study.

\section{State of the Art}

\section{Scaffold-Guided Technique}

The scaffold-guided approach uses a threedimensional structure that serves as a supportive framework for TEVG integration into the native vasculature. Synthetic polymers such as poly (glycolic acid) (PGA) and its variants poly (lactic acid) (PLA) and poly( $\varepsilon$-caprolactone) 
(PCL), which may be combined as copolymers, are used to fabricate scaffolds that degrade over time (Athanasiou et al. 1996; Patterson et al. 2012). The rate of degradation depends on various factors, including the properties of the materials used and the host's reaction to the materials. Longer degradation times maintain the mechanical properties of the scaffold for longer durations but also slow the remodeling process of the TEVG. Compared to natural material grafts, the construction of biodegradable synthetic TEVGs using various material ratios allows for more specific manipulation of biomechanical properties (Kim and Mooney 1998; Isenberg et al. 2006), but toxic byproducts from degradation and immunogenic response threaten graft incorporation (Higgins et al. 2003; Seifu et al. 2013).

Scaffolds derived from natural materials include those constructed with ECM-based gels, such as fibrin or collagen (Yao et al. 2005; Marelli et al. 2012), scaffolds constructed from decellularized allogenic or xenogenic tissue, or a combination of the two (Row et al. 2015). ECM-based grafts have an inherent bioactivity not seen in synthetic grafts (Hubbell 1999; Seifu et al. 2013) that promotes TEVG integration, but lack mechanical durability and consistency in comparison to synthetic grafts (Charulatha and Rajaram 2003; Badylak 2007). Decellularization is a process by which immunogenic cellular components are removed from tissues while maintaining the ECM framework for structure and biomechanical properties. Such a process enables endothelialization through seeding or ingrowth of host cells. Methods of tissue decellularization range from enzymatic digestion, detergent treatment, sonication, and hypo-/hypertonic immersion (Wilson et al. 1995). The degree of decellularization has not yet been optimized for TEVG fabrication, and xenografts may be associated with risk of pathogenic transmission from animal donor to human recipient (Leyh et al. 2006).

\section{Self-Assembled Cell-Sheet-Based Technique}

Sheet-based tissue engineering is a technique used to fabricate TEVGs with or without a scaf- fold while avoiding the use of exogenous materials. With this method, fibroblast and smooth muscle cells (SMCs) are cultured in a manner that generates ECM deposition in a cohesive sheet that can be carefully detached, yielding a single sheet of living cells with a well-organized and intact matrix (L'Heureux et al. 2006). These sheets are then placed onto the lumen of a scaffold and extensively cultured in bioreactors to form TEVGs with high burst pressures (McAllister et al. 2009). An alternative approach is the application of the cells to an agarose rod, which avoids the problems posed by removal of this layer with specialized machinery (Seifu et al. 2013). Though this alternative method avoids the use of specialized equipment, the conduits produced using this technique lack native biomechanical strength.

\section{Cell Sources}

Cell sources for TEVG fabrication include mature somatic cells, adult progenitor cells, and induced pluripotent stem (iPS) cells (Sundaram and Niklason 2012). Mature somatic cells, such as fibroblasts, SMCs, and ECs, can be harvested from the recipient, seeded on a selected scaffold, and implanted with little risk of immunogenic response. Bioactive substances released from ECs, including plasminogen factor, interleukin (IL)-1, fibronectin, heparin sulphate, and nitric oxide maintain homeostasis, antithrombogenicity, and increase vascular patency. SMCs form the vessel media and augment biomechanical properties such as contractility (Neff et al. 2011). Biodegradable PGA scaffolds seeded by the Niklason group with SMCs and ECs cultured under pulsatile radial stress conditions for 8 weeks showed mechanical properties similar to native human arteries (Niklason et al. 1999). Such TEVGs are in preparation for clinical application (Peck et al. 2012).

Because ECs and SMCs are terminally differentiated, these cells have a lower proliferative capacity compared to stem cells and progenitor cells. Extensively studied cells lines include embryonic stem cells (ESCs), induced pluripotent stem (iPS) cells, endothelial progenitor cells (EPCs), mesenchymal cells, and bone mar- 
E. Onwuka et al.

row-derived mononuclear stem cells (BMMNCs). ESC use in TEVG fabrication has been impeded by ethical concerns for embryo destruction and overall technical difficulty of harvesting these cells. However, such concerns may be nullified with the use of iPS cells, which can be derived from autologous fibroblast.

Our group prefers the use of BM-MNCs in producing TEVGs because of relative ease of harvesting these cells and the previous success experienced by our group using this cell type (Shin'oka et al. 2001, 2005; Hibino et al. 2010). Interestingly, our work thus far has shown that seeded cells do not actually populate the graft but disappear soon after implantation (Harrington et al. 2011). The BM-MNCs attract host cells from the nearby vessel via paracrine signaling (Hibino et al. 2011a). These findings conflict with the classic tissue-engineering paradigm that cells must be seeded onto the graft and allowed to populate the scaffold before implantation. We instead uphold that grafts can be seeded and implanted the same day. The transition to the use of the host as the bioreactor for the TEVG liberates cardiovascular tissue engineering from the time-consuming and expensive constraints imposed by ex vivo bioreactors (Hibino et al. 2005; Li and Henry 2011; Li et al. 2014).

\section{Clinical Application}

In 2001, 25 patients with an average age of 5 years underwent extracardiac total cavopulmonary conduit implantation using biodegradable TEVGs seeded with BM-MNCs (Fig. 1A-C) (Shin'oka et al. 2005). At 1 year, there was one patient diagnosed with partial mural thrombus who was treated successfully with anticoagulation. A late-term follow-up (average 5.8 years postimplantation) showed that four patients who developed TEVG stenosis were successfully treated with balloon angioplasty or stenting (Fig. 1D-G) (Hibino et al. 2010). The tissueengineered vascular conduits had reduced incidence of calcification, with no risk of rejection
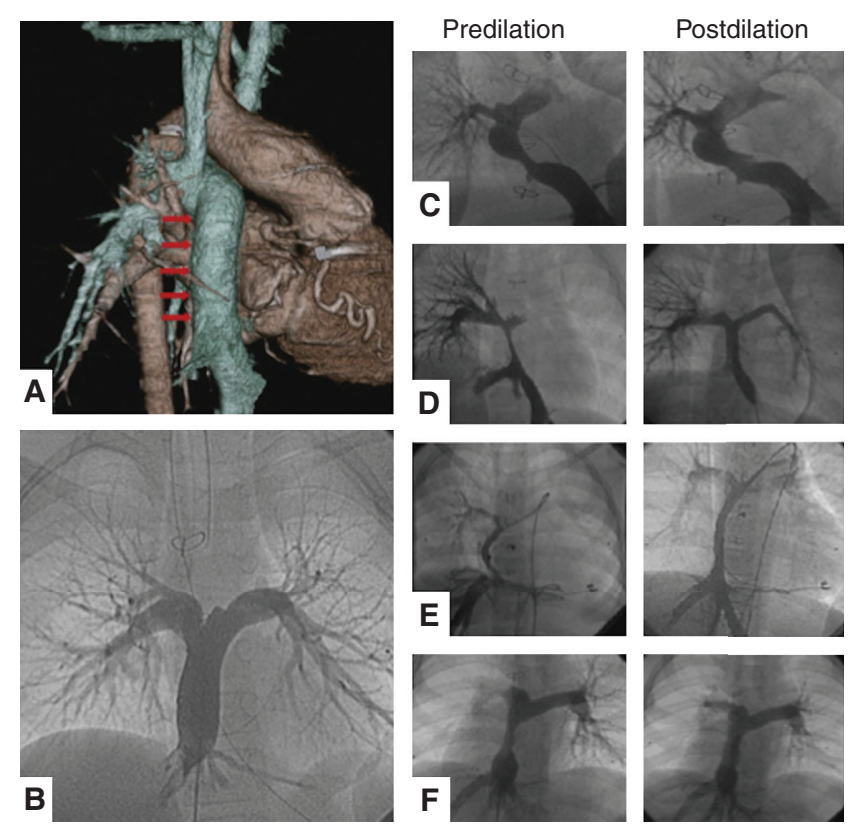

Figure 1. Late-term results of an extracardiac tissue-engineered vascular grafts implanted in humans during the modified Fontan procedure. (A) Three-dimensional computer tomography (CT) 1 year after implantation shows a patent graft with no aneurysmal dilation. $(B)$ Tissue-engineered vascular graft (TEVG) angiography 4 years after implantation with no malformations. $(C-F)$ Successful balloon angioplasty of four patients with TEVG stenosis. (From Hibino et al. 2010; adapted, with permission, from Elsevier (C) 2010.) 
because of autologous cell seeding, minimal risk of infection, and potential for growth (Breuer 2011). Following the excellent results of Shinoka et al., our group is currently performing the first FDA-approved human clinical trial investigating use of TEVGs in children with congenital heart disease.

\section{Current Limitations}

Although successfully treated with angioplasty, the results of Shinoka et al. did show stenosis to be the most common graft-related complication and a major barrier to widespread clinical application. Small animal models were developed to study the mechanisms underlying TEVG neotissue development and stenosis (Fig. 2) (Hibino et al. 2011b; Lee et al. 2014) and have shown that macrophages are essential for neotissue formation (Roh et al. 2010; Hibino et al. 2011b), but extensive infiltration leads to stenosis. More recently, stenosis has been linked to a process called endothelial-to-mesenchymal transformation (Endo-MT), during which endothelial cells migrate deeper into the vessel wall and transition to a mesenchymal phenotype. If this occurs excessively, it can cause luminal narrowing. Endo-MT is driven by macrophage tissue transforming growth factor $\beta$ (TGF- $\beta$ ) signaling, and experiments using TGF- $\beta$ receptor blockers have shown decreased Endo-MT and increased graft patency (Duncan et al. 2015).

Despite successful use of TEVGs in highflow low-pressure circulatory systems shown in clinical trials (Shin'oka et al. 2001, 2005; Hibino et al. 2010), the application of tissue engineering to arterial revascularization has been limited (L'Heureux et al. 2006). The feasibility of such grafts for hemodialysis access has been established as the implanted Lifeline grafts (Cytograft Tissue Engineering, Novato, CA) in three patients showed vascular integrity over an 11-month course without signs of immunogenic responses (McAllister et al. 2009; Wystrychowski et al. 2014). In fact, multicenter trials are underway to evaluate the safety and efficacy of Cytograft and Humacyte graft use in this respect (Gui and Niklason 2014). Because our inability to replicate arterial biomechanical properties, aneurysmal dilation of the graft and rupture are complications associated with conduits placed in high-pressure systems (Mirensky et al. 2009). Scaffolds with a longer degradation time can be used to allow continued biomechanical support while the neotissue develops, but this can lead to a prolonged foreign body response and calcification (de Valence et al. 2012; Tara et al. 2014).

\section{Alternative Strategies and Future Direction}

Several characteristics of the scaffold play a large role in the eventual success or failure of the vascular graft. For example, porosity and fiber diameter have been shown to allow varying degrees of cellular infiltration as well as macrophage phenotypic differentiation (Wang et al. 2014). When considering the various scaffold properties that can be tested before arriving at an optimal design, it is easy to see that one can spend several lifetimes working with preclinical models before arriving at the perfect graft. A collaborative effort between our group and the laboratories of Jay Humphrey and Yadong Wang has therefore explored a more rational and systematic method of scaffold development using computational modeling. We developed an equation that successfully describes the biomechanical behavior of tissue-engineered venous grafts implanted in a murine model (Khosravi et al. 2015). The model accounts for several variables such as the rate of scaffold degradation and ECM turnover. Using the mechanical data obtained from grafts explanted at varying time points, the model can be calibrated in a way that allows it to accurately predict behavior over the entire life span of the vessel. Additionally, by feeding the model enough biomechanical data regarding the performance of grafts with varying porosity or fiber diameter, you can provide the model with enough information to run thousands of simulations in silico and provide a scaffold design that, once implanted, will most closely replicate native vessel performance. These experiments will hopefully provide a means of efficiently and rapidly designing vascular grafts and other tissue-engineered organs. 
E. Onwuka et al.

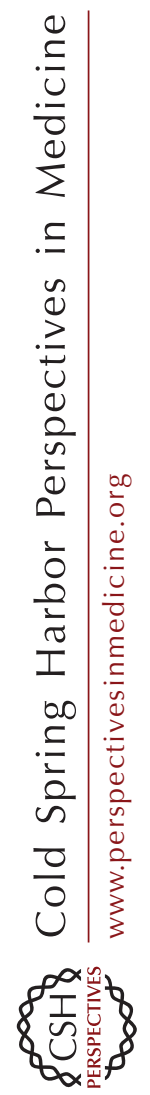

$\boldsymbol{m}$

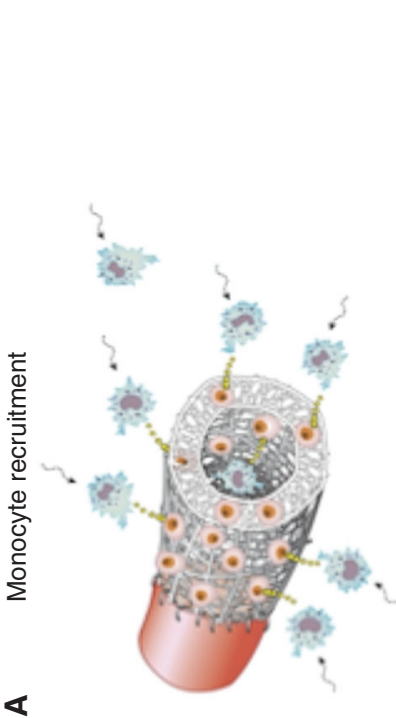

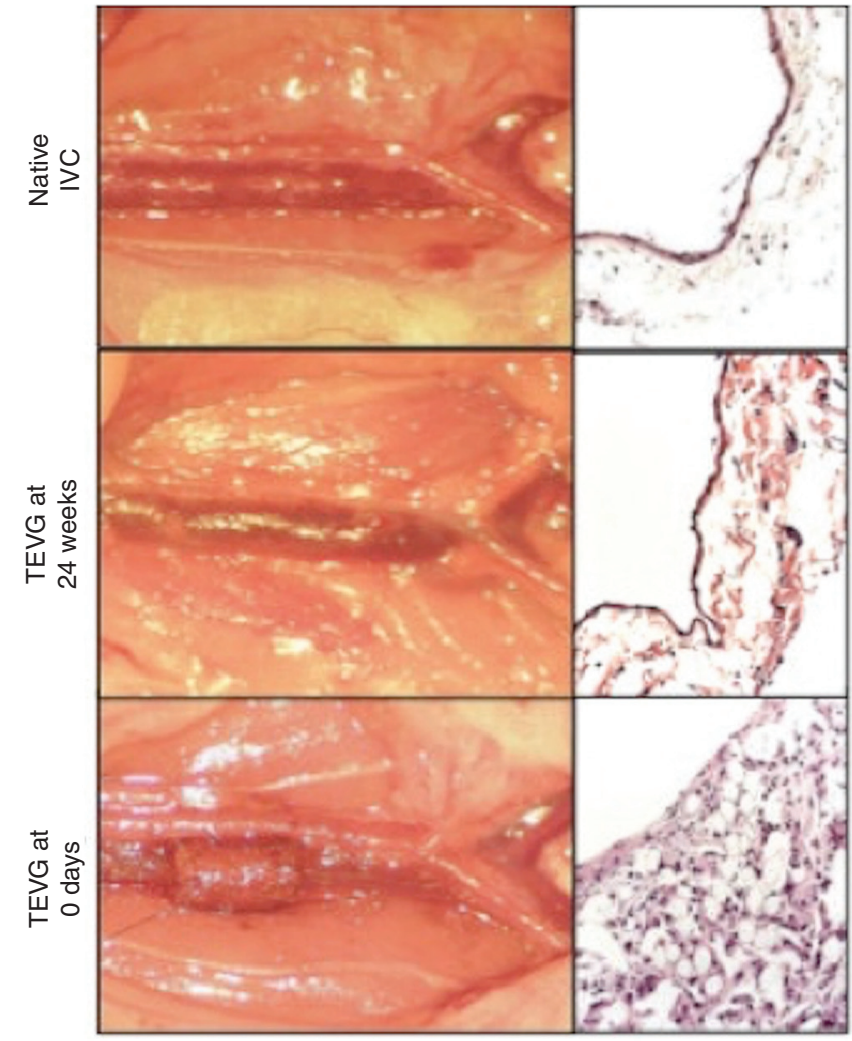

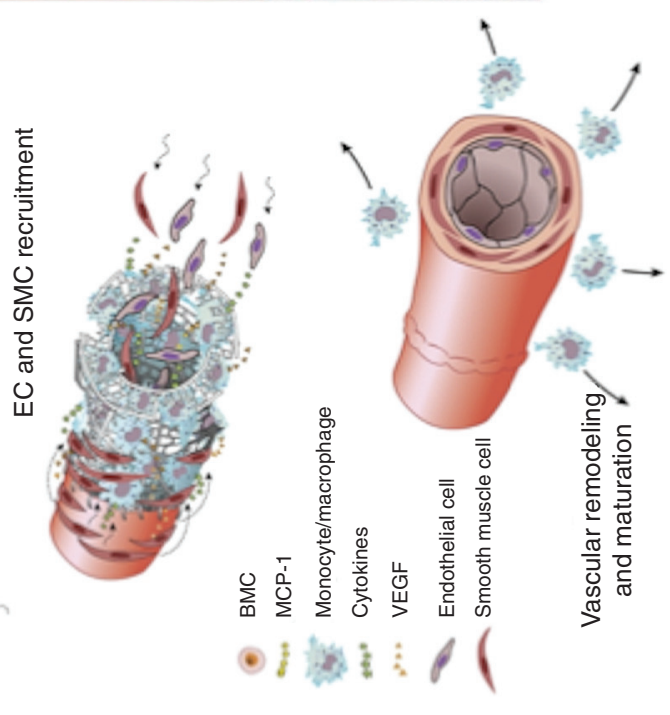

फั0

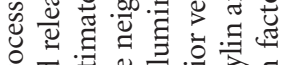

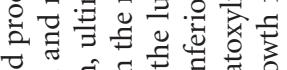

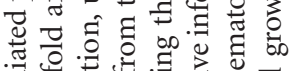

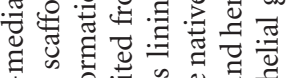

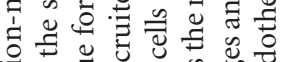

.

घี 웡

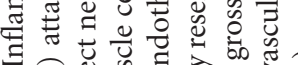

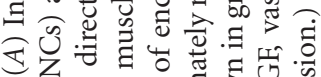

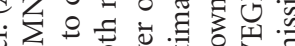

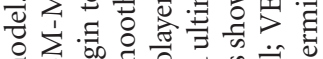
छ

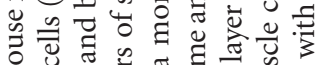

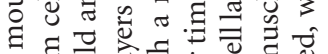

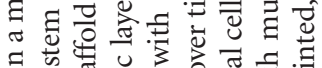

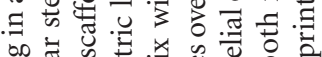

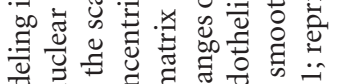
ठี

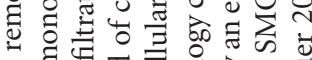
(ิ)

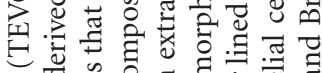

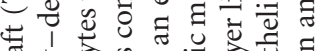
क्षे

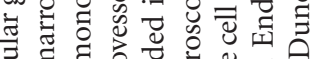

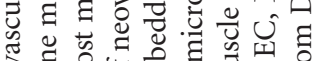

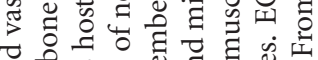

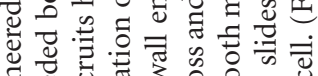
.

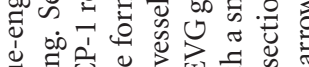

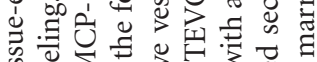

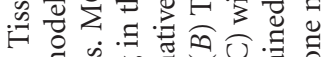
ن E

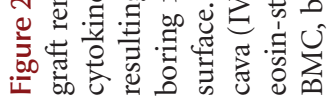




\section{MYOCARDIUM}

Much of the effort for myocardial tissue engineering has gone toward the development of a patch that can be used to replace diseased myocardium. An ideal cardiac patch would not only propagate spontaneous action potentials but would also connect with the host vasculature; couple electrically with the surrounding myocardium; and generate force to improve the function of the failing heart. Two major methods of fabricating a cardiac patch exist, the first of which involves stacking sheets of cells grown in culture and the second on growing cells on scaffolds before implantation. We speak briefly on each of these as well as the use of cell-injection therapies in myocardial engineering.

\section{State of the Art}

\section{Engineered Heart Tissue}

Much progress has been made in engineered heart tissue (EHT) since early experiments showed contractility of embryonic chicken cardiomyocytes grown in culture (Eschenhagen et al. 1997). Efforts have been aided by the natural propensity of immature cardiomyocytes to organize three-dimensionally and generate spontaneous action potentials (Hirt et al. 2014) — an attribute that is essential for the development of cell sheets. In this method, myocytes are cultured on plastic dishes and then detach in a single intact monolayer. These sheets can be stacked to form thicker structures capable of performing work (please see Shimizu et al. 2002 for examples of cell sheets). Both mechanical and electrical stimulation during the culture period are important for the development of these structures. Mechanical strain stimulates proper alignment and maturation of cells (Hirt et al. 2014) and can be induced either by way of static tension using suspension (Eschenhagen et al. 1997; Baar et al. 2005) or exposure to cyclic stretching using motorized devices (Tulloch et al. 2011; Zhang et al. 2012). Electrical stimulation promotes coupling of cardiac constructs and improves contractile function and cellular organization (Radisic et al. 2004; Tandon et al. 2009, 2011; Chiu et al. 2011; Vunjak-Novakovic et al. 2011; Maidhof et al. 2012).

\section{Scaffolds}

Synthetic or decellularized biologic scaffolds provide a three-dimensional structure on which cells can be cultured. The constituents and sizing specifications of the scaffold dictate the organization, maturation, and function of the forming tissue constructs. The scaffold materials used include, but are not limited to, the native heart matrix (Ott et al. 2008; Duan et al. 2011; Godier-Furnémont et al. 2011), natural hydrogels, such as collagen and Matrigel (Eschenhagen and Zimmermann 2005; Zimmermann et al. 2006; Song et al. 2010; Tiburcy et al. 2011), and synthetic polymers, such as poly(glycerol) sebacate (PGS) and polyacrylamide (Engelmayr et al. 2008; McCain et al. 2012; Zhang et al. 2012). Overall, the materials differ in the manner by which they are processed, their mechanical properties, their ultrastructure, and their biodegradability. Because of the great metabolic demand of cardiomyocytes, scaffold design must account for oxygen and nutrient delivery. Silvestri et al. provide a comprehensive review of scaffold formation for cardiac tissue engineering, including different scaffold types and fabrication methods (Silvestri et al. 2013).

\section{Clinical Application}

Successful preclinical animal models have led to several clinical trials and even clinical application of myocardial patches. Perhaps most notable is CorMatrix, which is constructed from decellularized porcine small intestinal submucosa (SIS). CorMatrix has been the subject of several preclinical (Mewhort et al. 2014) and clinical studies (Stelly and Stelly 2013; Yanagawa et al. 2014). Many of these studies report successful use, but there is some recent work documenting increased inflammatory response to the patch resulting in graft failure and necessitating removal (Rosario-Quinones et al. 2015; Woo et al. 2015). These studies also show poor integration of host cells into the scaffold. Long- 
E. Onwuka et al.

term data is needed to determine whether this technology will be a feasible solution.

\section{Current Limitations}

The inability to vascularize thick functional grafts has been a significant barrier of EHT fabrication. The thick cell-sheet myocardial constructs are not inherently vascularized and oxygen diffusion is limited. Therefore, the metabolic demand of cardiomyocytes is a trying impediment to the viability of such constructs. Sequentially stacking sheets onto the host myocardium allows vascularization of one layer after another (Shimizu et al. 2006), but this method has limited clinical application. Altering the cell types seeded onto the graft may allow formation of prevascularized patches, as shown in one study using cardiac patches created from human embryonic stem-cell-derived cardiomyocytes, human umbilical vein endothelial cells, and fibroblasts (Stevens et al. 2009). These grafts had microvessels that attached to the coronary circulation of rats on implantation and resulted in patches that were 10 -fold larger than the unvascularized counterparts when implanted in a skeletal muscle model (Stevens et al. 2009). Much work remains to be done, but this study serves as proof of concept that EHT can be vascularized, and vascularization results in thicker grafts similar to native myocardial tissue.

\section{Alternative Strategies and Future Endeavors}

An alternative approach to cardiac patches is the direct injection of either cells or biologic materials, such as collagen or alginate, into the diseased myocardium. Animal studies have shown that injection of fetal or neonatal cardiomyocytes improved left ventricular function and thickness, thus attenuating pathological remodeling after MI ( $\mathrm{Li}$ et al. 1996; Reinecke et al. 1999; Müller-Ehmsen et al. 2002; Huwer et al. 2003). However, these findings have limited clinical relevance because human fetal and neonatal cardiomyocytes cannot be readily obtained for transplantation because of ethical issues.
The search for a more clinically relevant cell source has led to the transplantation of skeletal myoblasts (Dorfman et al. 1998), embryonic stem-cell-derived cardiomyocytes (ESC-CMs) (Klug et al. 1996; Etzion et al. 2001; Kehat et al. 2001), bone marrow-derived mesenchymal stem cells (BM-MSCs) (Shake et al. 2002; Toma et al. 2002) and hematopoietic stem (HS) cells (Orlic et al. 2001; Balsam et al. 2004; Murry et al. 2004) into animal models of MI. The use of skeletal myoblasts and MSCs in this way has been translated to clinical trials. A meta-analysis of recent clinical trials with injection of bone marrow and peripheral blood mononuclear cells showed a significant, albeit low (3\%), increase in left ventricular ejection fraction (LVEF) in a dose-dependent manner as well as significant reductions in infarct size and end systolic volume in patients treated by intracoronary cell injection after acute MI (Lipinski et al. 2007). Injection of resident cardiac stem cells (SCIPIO, CADUCEUS) has also shown promising functional improvements in phase I clinical studies and restoration of viable tissue per magnetic resonance imaging (MRI), presumably because of the new CMs in addition to vascular cells (Bolli et al. 2011; Makkar et al. 2012).

Because of improving technologies, it is becoming more feasible to differentiate pluripotent stem cells, such as ESCs or induced pluripotent stem cells (iPSCs) into cardiomyocytes and to expand them to sufficient numbers to support the diseased myocardium. The discovery of human iPSCs (Takahashi et al. 2007) and the ability to generate cardiomyocytes from them (Zhang et al. 2009) could provide unlimited numbers of autologous cardiomyocytes for cell therapy without the ethical concerns raised by the use of human epithelial stem cells (hESCs). Studies from a number of groups have shown that it is possible to generate cardiomyocytes from mouse (Kattman et al. 2006) and human ESCs (Yang et al. 2008) and iPSCs (Zhang et al. 2009).

\section{HEART VALVES}

An ideal graft for heart valve replacement would be biocompatible, readily available, durable, 
and have the potential for growth and repair. Tissue engineering offers the potential to create such a nonthrombogenic, biomimetic, and immunologically compatible tissue (RabkinAikawa et al. 2005). This section focuses on the various methods of developing tissue-engineered heart valve (TEHV) with some insight provided on current limitations and new methodologies.

\section{State of the Art}

Similar to great vessel and myocardial tissue engineering, TEHV scaffolds can be manufactured from either synthetic or natural materials such as ECM components like collagen, fibrin, elastin, and glycosaminoglycans, or decellularized native tissues (Hodde 2002). Commonly used synthetic polymers in tissue engineering include PGA, poly(L-lactic acid) (PLLA), copolymer poly(lactic-co-glycolic acid) (PLGA), poly(ethylene glycol) (PEG), and polyhydroxyalkanoate (PHA).

\section{Biologic Scaffolds}

Given the complex structure of heart valves and the ability to maintain structure using decellularization methods, the most common biologic TEHV scaffolds have been decellularized allogenic or xenogenic tissues. Several preclinical studies using decellularized heart valve grafts have been documented in the literature (Iop and Gerosa 2015; James et al. 2015; Sierad et al. 2015; Syedain et al. 2015). The decellularized porcine SIS, CorMatrix, has also been used as a pulmonary valve replacement in porcine models (Matheny et al. 2000), with explanted constructs revealing resorption of the submucosal matrix, fibrous connective tissue growth, and formation of neovasculature. In a more recent study, Fallon et al. replaced the tricuspid valves in four sheep with the porcine SIS ECM sheet (Fallon et al. 2014). Explanted valves at $3,5,8$, and 12 months showed evidence of progressive tissue remodeling, host-cell infiltration, and structural reorganization of the ECM bioscaffold over the course of the study with no evidence of rejection.

\section{Synthetic Scaffolds}

Initial work using synthetic scaffolds focused on polymers composed of PGA and PLA (Breuer et al. 1996). However, the biomechanical profile of the construct is substantially different from that of a native heart valve. TEHVs fabricated using PGA and PLA copolymerbased matrices are thicker and less pliable than native valves. Hoerstrup and colleagues developed a novel composite scaffold material consisting of PGA mesh coated with a thin layer of poly-4-hydroxybutyrate (P4HB), which is a flexible, rapidly degradable, and thermoplastic polymer (Martin and Williams 2003). Autologous myofibroblasts and ECs from ovine carotid artery were seeded onto the scaffolds, cultured for 14 days in a bioreactor that gradually increased pressure and flow across the valve, and subsequently implanted in an ovine model (Hoerstrup et al. 2000). When explanted, they showed increased ECM synthesis, remodeling, and organization, as well as mechanical properties at 20 weeks that were almost indistinguishable from those of native valves.

\section{The Search for Appropriate Cell Sources}

An ideal cell source for TEHVs would show phenotypic plasticity and be able to adapt biomechanical properties in response to dynamic alterations in flow. A potential cell source for a TEHV would be autologous VICs and VECs. The use of these cells would eliminate the risk of rejection while maintaining the requisite phenotypic profile (Flanagan and Pandit 2003). However, to isolate and culture an adequate number of cells for clinical use from a small biopsy would be challenging, and the risks of such a procedure are formidable.

Autologous myofibroblasts derived from saphenous vein have similar phenotypic properties to VICs and represent a more feasible cell source for TEHV fabrication (Schnell et al. 2001). In a long-term TEHV study, the first of its kind, conducted by Dohmen et al. (2002), investigators seeded a decellularized pulmonary valve allograft with cells isolated from saphe- 
E. Onwuka et al.

nous vein and cultured in a bioreactor for 2 weeks. Results showed $100 \%$ survival with adequate valvular pressure gradients and no incidence of calcification at 10-year follow-up (Dohmen et al. 2002).

Likewise, mesenchymal stem cells show promise, although many of the details remain to be elucidated. Biodegradable polymeric scaffolds cultured with mesenchymal stem cells in vitro showed an organized internal structure and mature tissue development. Despite the encouraging results, it is not clear whether bone marrow stromal cells reliably differentiate into appropriate cell types in the scaffold or whether they continue to remain differentiated in vitro, ensuring long-term function and durability of the replacement heart valve (Perry et al. 2003). Investigations utilizing circulating endothelial and smooth muscle progenitor cells are at a similar stage (Simper et al. 2002). Given their remarkable differentiation potential, embryonic and adult stem cells may become valuable resources for heart valve tissue engineering, however, the former imposes ethical barriers.

\section{Cell-Seeding Techniques}

Traditional methods of seeding polymer scaffolds used static cell culture techniques in which a concentrated cell suspension is pipetted onto polymer scaffolds and left to incubate for various periods of time. In dynamic cell seeding, either the medium or the medium and scaffold are in constant motion during the incubation period. Dynamic cell seeding is often used in combination with a bioreactor and offers improved cellular attachment, infiltration, and alignment in the direction of flow in comparison to static cell seeding (Sutherland et al. 2002; Nasseri et al. 2003).

A bioreactor is a biomimetic system used to optimize in vitro neotissue development as it provides an environment for the graft that mimics in situ the physiologic or pathophysiologic conditions that are to be corrected with the engineered tissue. Factors such as shear stress, flow rate, flow profile, pressure, and media composition can be easily manipulated to change experimental conditions (Rippel et al. 2012). An ideal bioreactor for TEHVs should consist of pulsatile flow and cyclic flex to mimic the complex environment that implanted valves must withstand (Sacks and Yoganathan 2007). Exposure to pulsatile flow modulates the biomechanical properties of the neotissue, which is important for developing TEHVs that are resistant to premature valve deterioration (Hildebrand et al. 2004).

\section{Clinical Applications}

Dohmen et al. (2002) reported the first successful use of a TEHV using a decellularized cryopreserved pulmonary allograft. Since then, Dohmen and colleagues have published longterm follow-up data on a series of 11 patients, who underwent the Ross procedure with a TEHV to surgically reconstruct the right ventricular outflow tract. In each case, the allograft was seeded in a bioreactor with autologous vascular endothelial cells that had been isolated from a segment of forearm vein 2-4 weeks before the operation. At 10-year follow-up, the tissue-engineered heart valves showed excellent hemodynamic function. All patients remained in New York Heart Association class I heart failure and computed tomography showed no evidence of calcification or valve degeneration (Dohmen et al. 2011).

Early studies using decelluarized xenografts have not been as successful. In 2003, Simon et al. reported failure of SynerGraft decellularized porcine valves implanted in four children as pulmonary valves for right ventricular outflow tract reconstruction. Two valves evaluated at 6 weeks and 1 year were severely degenerated after implantation, and one valve ruptured 7 days after implantation, ultimately resulting in three deaths. The fourth child's valve was explanted because of cases of unfortunate mortality and morbidity (Simon et al. 2003). A more recent review conducted from 2006 to 2010 of 93 patients undergoing implantation of another decellularized xenograft type, Matrix P/Matrix P Plus, for right outflow tract reconstruction also showed high incidence of graft failure (Perri et al. 2012). 
There have been more promising results with decellularized allografts, shown by pulmonary valves decellularized using the same SynerGraft technology of the xenograft fabrication process. Studies published to date show decreased short-term stenosis or regurgitation, decreased clinically significant insufficiency, lower peak valve gradients, and fewer interventions in SynerGraft decellularized allogenic grafts when compared to standard cryopreserved valves (Tavakkol et al. 2005). Brown and colleagues performed a multicenter retrospective cohort study of 342 patients undergoing right ventricular outflow tract reconstruction with SynerGraft or standard cryopreserved valves and showed decreased regurgitation in the SynerGraft group and overall safety and efficacy at 4 years postimplantation (Brown et al. 2010).

\section{Current Limitations}

Despite having cellular components removed, deceullarized grafts still have the propensity to elicit an immune response. One reason for their continued immogenicity may be incomplete valve decellularization (Paniagua Gutierrez et al. 2015). Incomplete penetrance during the process can lead to cellular remnants that cause inflammatory response days after implantation (Simon et al. 2003). This immune reaction may also be against the extracellular matrix itself. A review of patients receiving Matrix $P$ decellularized pulmonary grafts also noted giant-type inflammatory cells on explanted samples, supporting an immune reaction similar to a foreign body response (Perri et al. 2012). There was also limited repopulation of the graft with host cells, which is another limitation of this technology noted by other studies as well (Cicha et al. 2011).

\section{Alternative Strategies and Future Endeavors}

An alternative method to scaffold formation introduced by the Hoerstrup group combines the use of synthetic biomaterials with decellularization to create "off-the-shelf" homologous valves for implantation (Dijkman et al. 2012).
Scaffolds created from a nonwoven polygylcolic acid mesh and coated with poly-4-hydroxybutyrate (PGA/P4HB) are seeded with human vascular-derived fibroblasts and incubated in a bioreactor for 4 weeks, during which time the seeded cells produce layered collagen along the graft. The scaffold is then decellularized. After implantation in nonhuman primates as pulmonary valve replacements, these valves showed layered collagen formation and substantial, homogenous cellular repopulation by host cells after 8 weeks, allowing the grafts to reach a cellularity comparable to that of native valves (Weber et al. 2013). Syedain et al. (2015) had comparable results using a similar method, but with a fibrin-based scaffold in an ovine model. The grafts showed graft endothelialization and host-cell repopulation after 6 months. By growing homologous cells on biodegradable scaffolds, the immunologic challenge imposed by xenogenic transplants is avoided. This technology can potentially solve the problem of demand associated with use of homografts.

Another important advancement in TEHV research is the development of catheter-based delivery systems for valve implantation (Schmidt et al. 2010; Moreira et al. 2015). Tissue-engineered valves can be loaded onto stents and inserted transapically for deployment into the pulmonary (Weber et al. 2013; Driessen-Mol et al. 2014; Schlegel et al. 2015) or aortic (Emmert et al. 2012) position. Though this technique requires a mini-sternotomy to expose the apex of the heart, it shows the use of catheter-based delivery methods for tissue-engineered technology. This application of minimally invasive medicine may open the door to fetal intervention with the novel therapies offered by tissue engineering. Correction of congenital malformations before birth may prevent the secondary sequalae of cardiovascular defects and prevent fetal demise (Weber et al. 2012).

\section{WHOLE HEART}

Much of the research regarding whole heart tissue engineering are proof-of-concept studies testing the effectiveness of decellularization methods. Decellularization of native heart ma- 
E. Onwuka et al.

terial is a powerful approach to easily recapitulate the in vivo architecture and extracellular composition of the heart. In 2008, Ott et al. decellularized whole rat hearts using a perfusion system of $1 \%$ sodium dodecyl sulfate (SDS) in deionized water (Ott et al. 2008). When reperfused, the decellularized heart maintained its vascular channels, demonstrating the preservation of overall native morphology. When reseeded with neonatal rat cells, the heart regained a cellularized appearance, and sections cut from the reseeded heart were able to propagate action potentials initiated by an external source. The whole heart graft also showed pharmacological responsiveness to phenylephrine. Overall, this study provided a basis for whole heart decellularization with subsequent repopulation, but much work is left to be performed as the model only provided a cardiac pump function at $2 \%$ of the adult rat heart output (see Ott et al. 2008 for images of decellularized rat hearts).

\section{SUMMARY}

The increasing incidence of CVD and the limited availability of transplant organs have more than validated the field of cardiovascular tissue engineering. Various scaffolds and biologic tissue have been used to recapitulate the native architecture of the heart and great vessels. Significant advances have been made in scaffold development, manipulation of progenitor cells for seeding, bioreactor development for culturing, and, more recently, minimally invasive delivery of tissue-engineered organs to target sites. However, several questions remain unanswered, and the complexity behind such questions necessitates collaborative efforts across disciplinary fields. Future clinical application of this novel approach depends on it.

\section{REFERENCES}

Athanasiou KA, Niederauer GG, Agrawal CM. 1996. Sterilization, toxicity, biocompatibility and clinical applications of polylactic acid/polyglycolic acid copolymers. Biomaterials 17: 93-102.

Baar K, Birla R, Boluyt MO, Borschel GH, Arruda EM, Dennis RG. 2005. Self-organization of rat cardiac cells into contractile 3-D cardiac tissue. FASEB J 19: 275-277.
Badylak SF. 2007. The extracellular matrix as a biologic scaffold material. Biomaterials 28: 3587-3593.

Balsam LB, Wagers AJ, Christensen JL, Kofidis T, Weissman IL, Robbins RC. 2004. Haematopoietic stem cells adopt mature haematopoietic fates in ischaemic myocardium. Nature 428: 668-673.

Bolli R, Chugh AR, D'Amario D, Loughran JH, Stoddard MF, Ikram S, Beache GM, Wagner SG, Leri A, Hosoda T, et al. 2011. Cardiac stem cells in patients with ischaemic cardiomyopathy (SCIPIO): Initial results of a randomised phase 1 trial. Lancet (London, England) 378: 1847-1857.

Breuer CK. 2011. The development and translation of the tissue-engineered vascular graft. J Pediatr Surg 46: 8-17.

Breuer CK, Shinoka T, Tanel RE, Zund G, Mooney DJ, Ma PX, Miura T, Colan S, Langer R, Mayer JE, et al. 1996. Tissue engineering lamb heart valve leaflets. Biotechnol Bioeng 50: 562-567.

Brown JW, Elkins RC, Clarke DR, Tweddell JS, Huddleston CB, Doty JR, Fehrenbacher JW, Takkenberg JJM. 2010. Performance of the CryoValve SG human decellularized pulmonary valve in 342 patients relative to the conventional CryoValve at a mean follow-up of four years. J Thorac Cardiovasc Surg 139: 339-348.

Cannegieter SC, Rosendaal FR, Briët E. 1994. Thromboembolic and bleeding complications in patients with mechanical heart valve prostheses. Circulation 89: 635-641.

Charulatha V, Rajaram A. 2003. Influence of different crosslinking treatments on the physical properties of collagen membranes. Biomaterials 24: 759-767.

Chiu LLY, Iyer RK, King J-P, Radisic M. 2011. Biphasic electrical field stimulation aids in tissue engineering of multicell-type cardiac organoids. Tissue Eng Part A 17: 1465-1477.

Cicha I, Rüffer A, Cesnjevar R, Glöckler M, Agaimy A, Daniel WG, Garlichs CD, Dittrich S. 2011. Early obstruction of decellularized xenogenic valves in pediatric patients: Involvement of inflammatory and fibroproliferative processes. Cardiovasc Pathol 20: 222-231.

Cole WG, Chan D, Hickey A J, Wilcken DE. 1984. Collagen composition of normal and myxomatous human mitral heart valves. Biochem J 219: 451-460.

de Valence S, Tille J-C, Mugnai D, Mrowczynski W, Gurny R, Möller M, Walpoth BH. 2012. Long term performance of polycaprolactone vascular grafts in a rat abdominal aorta replacement model. Biomaterials 33: 38-47.

Dijkman PE, Driessen-Mol A, Frese L, Hoerstrup SP, Baaijens FPT. 2012. Decellularized homologous tissue-engineered heart valves as off-the-shelf alternatives to xeno- and homografts. Biomaterials 33: 4545-4554.

Dohmen PM, Lembcke A, Hotz H, Kivelitz D, Konertz WF. 2002. Ross operation with a tissue-engineered heart valve. Ann Thorac Surg 74: 1438-1442.

Dohmen PM, Lembcke A, Holinski S, Pruss A, Konertz W. 2011. Ten years of clinical results with a tissue-engineered pulmonary valve. Ann Thorac Surg 92: 1308-1314.

Dorfman J, Duong M, Zibaitis A, Pelletier MP, Shum-Tim D, Li C, Chiu RC. 1998. Myocardial tissue engineering with autologous myoblast implantation. J Thorac Cardiovasc Surg 116: 744-751. 
Driessen-Mol A, Emmert MY, Dijkman PE, Frese L, Sanders B, Weber B, Cesarovic N, Sidler M, Leenders J, Jenni R, et al. 2014. Transcatheter implantation of homologous "offthe-shelf" tissue-engineered heart valves with self-repair capacity: Long-term functionality and rapid in vivo remodeling in sheep. J Am Coll Cardiol 63: 1320-1329.

Duan Y, Liu Z, O'Neill J, Wan LQ, Freytes DO, VunjakNovakovic G. 2011. Hybrid gel composed of native heart matrix and collagen induces cardiac differentiation of human embryonic stem cells without supplemental growth factors. J Cardiovasc Transl Res 4: 605-615.

Duncan DR, Breuer CK. 2011. Challenges in translating vascular tissue engineering to the pediatric clinic. Vasc Cell 3: 23.

Duncan DR, Chen PY, Patterson JT, Lee YU, Hibino N, Cleary M, Naito Y, Yi T, Gilliland T, Kurobe H, et al. 2015. TGF $\beta R 1$ inhibition blocks the formation of stenosis in tissue-engineered vascular grafts. J Am Coll Cardiol 65: $512-514$.

Emmert MY, Weber B, Wolint P, Behr L, Sammut S, Frauenfelder T, Frese L, Scherman J, Brokopp CE, Templin C, et al. 2012. Stem cell-based transcatheter aortic valve implantation: First experiences in a pre-clinical model. JACC Cardiovasc Interv 5: 874-883.

Engelmayr GC, Cheng M, Bettinger CJ, Borenstein JT, Langer R, Freed LE. 2008. Accordion-like honeycombs for tissue engineering of cardiac anisotropy. Nat Mater 7: 1003-1010.

Eschenhagen T, Zimmermann WH. 2005. Engineering myocardial tissue. Circ Res 97: 1220-1231.

Eschenhagen T, Fink C, Remmers U, Scholz H, Wattchow J, Weil J, Zimmermann W, Dohmen HH, Schäfer H, Bishopric N, et al. 1997. Three-dimensional reconstitution of embryonic cardiomyocytes in a collagen matrix: A new heart muscle model system. FASEB J 11: 683-694.

Etzion S, Battler A, Barbash IM, Cagnano E, Zarin P, Granot Y, Kedes LH, Kloner RA, Leor J. 2001. Influence of embryonic cardiomyocyte transplantation on the progression of heart failure in a rat model of extensive myocardial infarction. J Mol Cell Cardiol 33: 1321-1330.

Fallon AM, Goodchild TT, Cox JL, Matheny RG. 2014. In vivo remodeling potential of a novel bioprosthetic tricuspid valve in an ovine model. $J$ Thorac Cardiovasc Surg 148: 333-340.el.

Flanagan TC, Pandit A. 2003. Living artificial heart valve alternatives: A review. Eur Cell Mater 6: 28-45; discussion 45 .

Godier-Furnémont AFG, Martens TP, Koeckert MS, Wan L, Parks J, Arai K, Zhang G, Hudson B, Homma S, VunjakNovakovic G. 2011. Composite scaffold provides a cell delivery platform for cardiovascular repair. Proc Natl Acad Sci 108: 7974-7979.

Gui L, Niklason LE. 2014. Vascular tissue engineering: Building perfusable vasculature for implantation. Curr Opin Chem Eng 3: 68-74.

Hammermeister K, Sethi GK, Henderson WG, Grover FL, Oprian C, Rahimtoola SH. 2000. Outcomes 15 years after valve replacement with a mechanical versus a bioprosthetic valve: Final report of the Veterans Affairs randomized trial. J Am Coll Cardiol 36: 1152-1158.

Harrington JK, Chahboune H, Criscione JM, Li AY, Hibino N, Yi T, Villalona GA, Kobsa S, Meijas D, Duncan DR, et al. 2011. Determining the fate of seeded cells in venous tissue-engineered vascular grafts using serial MRI. FASEB J 25: 4150-4161.

Hibino N, Shin'oka T, Matsumura G, Ikada Y, Kurosawa H. 2005. The tissue-engineered vascular graft using bone marrow without culture. J Thorac Cardiovasc Surg 129: 1064-1070.

Hibino N, McGillicuddy E, Matsumura G, Ichihara Y, Naito Y, Breuer C, Shinoka T. 2010. Late-term results of tissueengineered vascular grafts in humans. J Thorac Cardiovasc Surg 139: 431-436, 436.el-2.

Hibino N, Villalona G, Pietris N, Duncan DR, Schoffner A, Roh JD, Yi T, Dobrucki LW, Mejias D, Sawh-Martinez R, et al. 2011a. Tissue-engineered vascular grafts form neovessels that arise from regeneration of the adjacent blood vessel. FASEB J 25: 2731-2739.

Hibino N, Yi T, Duncan DR, Rathore A, Dean E, Naito Y, Dardik A, Kyriakides T, Madri J, Pober JS, et al. 2011b. A critical role for macrophages in neovessel formation and the development of stenosis in tissue-engineered vascular grafts. FASEB J 25: 4253-4263.

Higgins SP, Solan AK, Niklason LE. 2003. Effects of polyglycolic acid on porcine smooth muscle cell growth and differentiation. J Biomed Mater Res A 67: 295-302.

Hildebrand DK, Wu ZJ, Mayer JE, Sacks MS. 2004. Design and hydrodynamic evaluation of a novel pulsatile bioreactor for biologically active heart valves. Ann Biomed Eng 32: 1039-1049.

Hirt MN, Hansen A, Eschenhagen T. 2014. Cardiac tissue engineering: State of the art. Circ Res 114: 354-367.

Hodde J. 2002. Naturally occurring scaffolds for soft tissue repair and regeneration. Tissue Eng 8: 295-308.

Hoerstrup SP, Sodian R, Daebritz S, Wang J, Bacha EA, Martin DP, Moran AM, Guleserian KJ, Sperling JS, Kaushal S, et al. 2000. Functional living trileaflet heart valves grown in vitro. Circulation 102: III44-III49.

Hubbell JA. 1999. Bioactive biomaterials. Curr Opin Biotechnol 10: 123-129.

Huwer H, Winning J, Vollmar B, Welter C, Löhbach C, Menger MD, Schäfers HJ. 2003. Long-term cell survival and hemodynamic improvements after neonatal cardiomyocyte and satellite cell transplantation into healed myocardial cryoinfarcted lesions in rats. Cell Transplant 12: $757-767$.

Iop L, Gerosa G. 2015. Guided tissue regeneration in heart valve replacement: From preclinical research to first-inhuman trials. Biomed Res Int 2015: 432901.

Isenberg BC, Williams C, Tranquillo RT. 2006. Small-diameter artificial arteries engineered in vitro. Circ Res 98: 2535.

James IA, Yi T, Tara S, Best CA, Stuber AJ, Shah KV, Austin BF, Sugiura T, Lee YU, Lincoln J, et al. 2015. Hemodynamic characterization of a mouse model for investigating the cellular and molecular mechanisms of neotissue formation in tissue-engineered heart valves. Tissue Eng Part C Methods 21: 987-994.

Kattman SJ, Huber TL, Keller GM. 2006. Multipotent flk-1 ${ }^{+}$ cardiovascular progenitor cells give rise to the cardiomyocyte, endothelial, and vascular smooth muscle lineages. Dev Cell 11: 723-732. 


\section{E. Onwuka et al.}

Kehat I, Kenyagin-Karsenti D, Snir M, Segev H, Amit M Gepstein A, Livne E, Binah O, Itskovitz-Eldor J, Gepstein L. 2001. Human embryonic stem cells can differentiate into myocytes with structural and functional properties of cardiomyocytes. J Clin Invest 108: 407-414.

Khosravi R, Miller KS, Best CA, Shih YC, Lee YU, Yi T, Shinoka T, Breuer CK, Humphrey JD. 2015. Biomechanical diversity despite mechanobiological stability in tissue engineered vascular grafts two years post-implantation. Tissue Eng Part A 21: 1529-1538.

Kim BS, Mooney DJ. 1998. Development of biocompatible synthetic extracellular matrices for tissue engineering. Trends Biotechnol 16: 224-230.

Klug MG, Soonpaa MH, Koh GY, Field LJ. 1996. Genetically selected cardiomyocytes from differentiating embryonic stem cells form stable intracardiac grafts. J Clin Invest 98: 216-224.

Kumar V, Abbas AK, Fausto N, Aster JC. 2010. Robbins and Cotran pathologic basis of disease, 8th ed. Elsevier, Philadelphia.

Langer R, Vacanti J. 1993. Tissue engineering. Science 260: 920-926.

Lee YU, Yi T, Tara S, Lee AY, Hibino N, Shinoka T, Breuer CK. 2014. Implantation of inferior vena cava interposition graft in mouse model. J Vis Exp doi: 10.3791/51632.

Leyh RG, Wilhelmi M, Rebe P, Ciboutari S, Haverich A, Mertsching H. 2006. Tissue engineering of viable pulmonary arteries for surgical correction of congenital heart defects. Ann Thorac Surg 81: 1466-1470.

L'Heureux N, Dusserre N, Konig G, Victor B, Keire P, Wight TN, Chronos NAF, Kyles AE, Gregory CR, Hoyt G, et al. 2006. Human tissue-engineered blood vessels for adult arterial revascularization. Nat Med 12: 361-365.

Li S, Henry JJD. 2011. Nonthrombogenic approaches to cardiovascular bioengineering. Annu Rev Biomed Eng 13: $451-475$.

Li RK, Jia ZQ, Weisel RD, Mickle DA, Zhang J, Mohabeer MK, Rao V, Ivanov J. 1996. Cardiomyocyte transplantation improves heart function. Ann Thorac Surg 62: 654660; discussion 660-661.

Li S, Sengupta D, Chien S. 2014. Vascular tissue engineering: From in vitro to in situ. Wiley Interdiscip Rev Syst Biol Med 6: 61-76.

Lipinski MJ, Biondi-Zoccai GGL, Abbate A, Khianey R, Sheiban I, Bartunek J, Vanderheyden M, Kim H-S, Kang HJ, Strauer BE, et al. 2007. Impact of intracoronary cell therapy on left ventricular function in the setting of acute myocardial infarction: A collaborative systematic review and meta-analysis of controlled clinical trials. J Am Coll Cardiol 50: 1761-1767.

Maidhof R, Tandon N, Lee EJ, Luo J, Duan Y, Yeager K, Konofagou E, Vunjak-Novakovic G. 2012. Biomimetic perfusion and electrical stimulation applied in concert improved the assembly of engineered cardiac tissue. J Tissue Eng Regen Med 6: e12-e23.

Makkar RR, Smith RR, Cheng K, Malliaras K, Thomson LEJ, Berman D, Czer LSC, Marbán L, Mendizabal A, Johnston $\mathrm{PV}$, et al. 2012. Intracoronary cardiosphere-derived cells for heart regeneration after myocardial infarction (CADUCEUS): A prospective, randomised phase 1 trial. Lancet (London, England) 379: 895-904.
Manji RA, Menkis AH, Ekser B, Cooper DKC. 2012. Porcine bioprosthetic heart valves: The next generation. Am Heart J 164: 177-185.

Marelli B, Achilli M, Alessandrino A, Freddi G, Tanzi MC, Farè S, Mantovani D. 2012. Collagen-reinforced electrospun silk fibroin tubular construct as small calibre vascular graft. Macromol Biosci 12: 1566-1574.

Martin DP, Williams SF. 2003. Medical applications of poly4-hydroxybutyrate: A strong flexible absorbable biomaterial. Biochem Eng J 16: 97- 105.

Matheny RG, Hutchison ML, Dryden PE, Hiles MD, Shaar CJ. 2000. Porcine small intestine submucosa as a pulmonary valve leaflet substitute. J Heart Valve Dis 9: 769-774; discussion 774-775.

McAllister TN, Maruszewski M, Garrido SA, Wystrychowski W, Dusserre N, Marini A, Zagalski K, Fiorillo A, Avila H, Manglano X, et al. 2009. Effectiveness of haemodialysis access with an autologous tissue-engineered vascular graft: A multicentre cohort study. Lancet 373: 1440-1446.

McCain ML, Lee H, Aratyn-Schaus Y, Kleber AG, Parker KK. 2012. Cooperative coupling of cell-matrix and cell-cell adhesions in cardiac muscle. Proc Natl Acad Sci 109: 9881-9886.

Mewhort HEM, Turnbull JD, Meijndert HC, Ngu JMC, Fedak PWM. 2014. Epicardial infarct repair with basic fibroblast growth factor-enhanced CorMatrix-ECM biomaterial attenuates postischemic cardiac remodeling. J Thorac Cardiovasc Surg 147: 1650-1659.

Mirensky TL, Nelson GN, Brennan MP, Roh JD, Hibino N, Yi T, Shinoka T, Breuer CK. 2009. Tissue-engineered arterial grafts: Long-term results after implantation in a small animal model. J Pediatr Surg 44: 1127-1132; discussion 1132-1133.

Moreira R, Velz T, Alves N, Gesche VN, Malischewski A, Schmitz-Rode T, Frese J, Jockenhoevel S, Mela P. 2015. Tissue-engineered heart valve with a tubular leaflet design for minimally invasive transcatheter implantation. Tissue Eng Part C Methods 21: 530-540.

Müller-Ehmsen J, Peterson KL, Kedes L, Whittaker P, Dow JS, Long TI, Laird PW, Kloner RA. 2002. Rebuilding a damaged heart: Long-term survival of transplanted neonatal rat cardiomyocytes after myocardial infarction and effect on cardiac function. Circulation 105: 1720-1726.

Murry CE, Soonpaa MH, Reinecke H, Nakajima H, Nakajima HO, Rubart M, Pasumarthi KBS, Virag JI, Bartelmez SH, Poppa V, et al. 2004. Haematopoietic stem cells do not transdifferentiate into cardiac myocytes in myocardial infarcts. Nature 428: 664-668.

Mykén PSU, Bech-Hansen O. 2009. A 20-year experience of 1712 patients with the Biocor porcine bioprosthesis. J Thorac Cardiovasc Surg 137: 76-81.

Nasseri BA, Pomerantseva I, Kaazempur-Mofrad MR, Sutherland FWH, Perry T, Ochoa E, Thompson CA, Mayer JEJr, Oesterle SN, Vacanti JP, et al. 2003. Dynamic rotational seeding and cell culture system for vascular tube formation. Tissue Eng 9: 291-299.

Neff LP, Tillman BW, Yazdani SK, Machingal MA, Yoo JJ, Soker S, Bernish BW, Geary RL, Christ GJ. 2011. Vascular smooth muscle enhances functionality of tissue-engineered blood vessels in vivo. J Vasc Surg 53: 426-434. 
Niklason LE, Gao J, Abbott WM, Hirschi KK, Houser S, Marini R, Langer R. 1999. Functional arteries grown in vitro. Science 284: 489-493.

Orlic D, Kajstura J, Chimenti S, Jakoniuk I, Anderson SM, Li B, Pickel J, McKay R, Nadal-Ginard B, Bodine DM, et al. 2001. Bone marrow cells regenerate infarcted myocardium. Nature 410: 701-705.

Ott HC, Matthiesen TS, Goh S-K, Black LD, Kren SM, Netoff TI, Taylor DA. 2008. Perfusion-decellularized matrix: Using nature's platform to engineer a bioartificial heart. Nat Med 14: 213-221.

Paniagua Gutierrez JR, Berry H, Korossis S, Mirsadraee S, Lopes SV, da Costa F, Kearney J, Watterson K, Fisher J, Ingham E. 2015. Regenerative potential of low-concentration SDS-decellularized porcine aortic valved conduits in vivo. Tissue Eng Part A 21: 332-342.

Patterson JT, Gilliland T, Maxfield MW, Church S, Naito Y, Shinoka T, Breuer CK. 2012. Tissue-engineered vascular grafts for use in the treatment of congenital heart disease: From the bench to the clinic and back again. Regen Med 7: 409-419.

Peck M, Gebhart D, Dusserre N, McAllister TN, L'Heureux N. 2012. The evolution of vascular tissue engineering and current state of the art. Cells Tissues Organs 195: 144158.

Perri G, Polito A, Esposito C, Albanese SB, Francalanci P, Pongiglione G, Carotti A. 2012. Early and late failure of tissue-engineered pulmonary valve conduits used for right ventricular outflow tract reconstruction in patients with congenital heart disease. Eur J Cardiothorac Surg 41: $1320-1325$.

Perry T, Kaushal S, Sutherland FW, Guleserian K, Bischoff J, Sacks M, Mayer J. 2003. Bone marrow as a cell source for tissue engineering heart valves. Ann Thorac Surg 75: 761 767.

Pibarot P, Dumesnil JG. 2009. Prosthetic heart valves: Selection of the optimal prosthesis and long-term management. Circulation 119: 1034-1048.

Rabkin-Aikawa E, Mayer JE, Schoen FJ. 2005. Heart valve regeneration. Adv Biochem Eng Biotechnol 94: 141-179.

Radisic M, Park H, Shing H, Consi T, Schoen FJ, Langer R, Freed LE, Vunjak-Novakovic G. 2004. Functional assembly of engineered myocardium by electrical stimulation of cardiac myocytes cultured on scaffolds. Proc Natl Acad Sci 101: 18129-18134.

Rahimtoola SH. 2003. Choice of prosthetic heart valve for adult patients. J Am Coll Cardiol 41: 893-904.

Rahimtoola SH. 2010. Choice of prosthetic heart valve in adults. An update. J Am Coll Cardiol 55: 2413-2426.

Reinecke H, Zhang M, Bartosek T, Murry CE. 1999. Survival, integration, and differentiation of cardiomyocyte grafts: A study in normal and injured rat hearts. Circulation 100: 193-202.

Rippel RA, Ghanbari H, Seifalian AM. 2012. Tissue-engineered heart valve: Future of cardiac surgery. World J Surg 36: 1581-1591.

Roh JD, Sawh-Martinez R, Brennan MP, Jay SM, Devine L, Rao DA, Yi T, Mirensky TL, Nalbandian A, Udelsman B, et al. 2010. Tissue-engineered vascular grafts transform into mature blood vessels via an inflammation-mediated process of vascular remodeling. Proc Natl Acad Sci 107: 4669-4674.

Rosario-Quinones F, Magid MS, Yau J, Pawale A, Nguyen K. 2015. Tissue reaction to porcine intestinal submucosa (CorMatrix) implants in pediatric cardiac patients: A single-center experience. Ann Thorac Surg 99: 13731377.

Row S, Peng H, Schlaich EM, Koenigsknecht C, Andreadis ST, Swartz DD. 2015. Arterial grafts exhibiting unprecedented cellular infiltration and remodeling in vivo: The role of cells in the vascular wall. Biomaterials 50: 115126.

Sacks MS, Yoganathan AP. 2007. Heart valve function: A biomechanical perspective. Philos Trans R Soc Lond B Biol Sci 362: 1369-1391.

Sales VL, Mettler BA, Engelmayr GC, Aikawa E, Bischoff J, Martin DP, Exarhopoulos A, Moses MA, Schoen FJ, Sacks MS, et al. 2010. Endothelial progenitor cells as a sole source for ex vivo seeding of tissue-engineered heart valves. Tissue Eng Part A 16: 257-267.

Sarkar S, Sales KM, Hamilton G, Seifalian AM. 2007. Addressing thrombogenicity in vascular graft construction. J Biomed Mater Res B Appl Biomater 82: 100-108.

Schlegel F, Salameh A, Oelmann K, Halling M, Dhein S, Mohr FW, Dohmen PM. 2015. Injectable tissue engineered pulmonary heart valve implantation into the pig model: A feasibility study. Med Sci Monit Basic Res 21: $135-140$.

Schmidt D, Dijkman PE, Driessen-Mol A, Stenger R, Mariani $C$, Puolakka A, Rissanen $M$, Deichmann T, Odermatt B, Weber B, et al. 2010. Minimally invasive implantation of living tissue engineered heart valves: A comprehensive approach from autologous vascular cells to stem cells. J Am Coll Cardiol 56: 510-520.

Schnell AM, Hoerstrup SP, Zund G, Kolb S, Sodian R, Visjager JF, Grunenfelder J, Suter A, Turina M. 2001. Optimal cell source for cardiovascular tissue engineering: Venous vs. aortic human myofibroblasts. Thorac Cardiovasc Surg 49: 221-225.

Schoen FJ. 2008. Evolving concepts of cardiac valve dynamics: The continuum of development, functional structure, pathobiology, and tissue engineering. Circulation 118: $1864-1880$.

Schoen FJ. 2011. Heart valve tissue engineering: Quo vadis? Curr Opin Biotechnol 22: 698-705.

Scott M, Vesely I. 1995. Aortic valve cusp microstructure: The role of elastin. Ann Thorac Surg 60: S391-S394.

Seifu DG, Purnama A, Mequanint K, Mantovani D. 2013. Small-diameter vascular tissue engineering. Nat Rev Cardiol 10: 410-421.

Shake JG, Gruber PJ, Baumgartner WA, Senechal G, Meyers J, Redmond JM, Pittenger MF, Martin BJ. 2002. Mesenchymal stem cell implantation in a swine myocardial infarct model: Engraftment and functional effects. Ann Thorac Surg 73: 1919-1925; discussion 1926.

Shimizu T, Yamato M, Isoi Y, Akutsu T, Setomaru T, Abe K, Kikuchi A, Umezu M, Okano T. 2002. Fabrication of pulsatile cardiac tissue grafts using a novel 3-dimensional cell sheet manipulation technique and temperature-responsive cell culture surfaces. Circ Res 90: e40. 


\section{E. Onwuka et al.}

Shimizu T, Sekine H, Yang J, Isoi Y, Yamato M, Kikuchi A, Kobayashi E, Okano T. 2006. Polysurgery of cell sheet grafts overcomes diffusion limits to produce thick, vascularized myocardial tissues. FASEB J 20: 708-710.

Shin'oka T, Imai Y, Ikada Y. 2001. Transplantation of a tissueengineered pulmonary artery. $N$ Engl J Med 344: $532-$ 533.

Shin'oka T, Matsumura G, Hibino N, Naito Y, Watanabe M, Konuma T, Sakamoto T, Nagatsu M, Kurosawa H. 2005. Midterm clinical result of tissue-engineered vascular autografts seeded with autologous bone marrow cells. J Thorac Cardiovasc Surg 129: 1330-1338.

Sierad LN, Shaw EL, Bina A, Brazile B, Rierson N, Patnaik SS, Kennamer A, Odum R, Cotoi O, Terezia P, et al. 2015. Functional heart valve scaffolds obtained by complete decellularization of porcine aortic roots in a novel differential pressure gradient perfusion system. Tissue Eng Part C Methods 21: 1284-1296.

Silvestri A, Boffito M, Sartori S, Ciardelli G. 2013. Biomimetic materials and scaffolds for myocardial tissue regeneration. Macromol Biosci 13: 984-1019.

Simon P, Kasimir MT, Seebacher G, Weigel G, Ullrich R, Salzer-Muhar U, Rieder E, Wolner E. 2003. Early failure of the tissue engineered porcine heart valve SYNERGRAFT in pediatric patients. Eur J Cardiothorac Surg 23: 1002-1006; discussion 1006.

Simper D, Stalboerger PG, Panetta CJ, Wang S, Caplice NM. 2002. Smooth muscle progenitor cells in human blood. Circulation 106: 1199-1204

Song H, Yoon C, Kattman SJ, Dengler J, Massé S, Thavaratnam T, Gewarges M, Nanthakumar K, Rubart M, Keller GM, et al. 2010. Interrogating functional integration between injected pluripotent stem cell-derived cells and surrogate cardiac tissue. Proc Natl Acad Sci 107: 3329-3334.

Stelly M, Stelly TC. 2013. Histology of CorMatrix bioscaffold 5 years after pericardial closure. Ann Thorac Surg 96: e127-e129.

Stevens KR, Kreutziger KL, Dupras SK, Korte FS, Regnier M, Muskheli V, Nourse MB, Bendixen K, Reinecke H, Murry CE. 2009. Physiological function and transplantation of scaffold-free and vascularized human cardiac muscle tissue. Proc Natl Acad Sci 106: 16568-16573.

Sundaram S, Niklason LE. 2012. Smooth muscle and other cell sources for human blood vessel engineering. Cells Tissues Organs 195: 15-25.

Sutherland FWH, Perry TE, Nasseri BA, Wang J, Kaushal S, Guleserian KJ, Martin DP, Vacant JP, Mayer JE. 2002. Advances in the mechanisms of cell delivery to cardiovascular scaffolds: Comparison of two rotating cell culture systems. ASAIO J 48: 346-349.

Syedain Z, Reimer J, Schmidt J, Lahti M, Berry J, Bianco R, Tranquillo RT. 2015. 6-Month aortic valve implantation of an off-the-shelf tissue-engineered valve in sheep. Biomaterials 73: 175-184.

Takahashi K, Tanabe K, Ohnuki M, Narita M, Ichisaka T, Tomoda K, Yamanaka S. 2007. Induction of pluripotent stem cells from adult human fibroblasts by defined factors. Cell 131: 861-872.

Tandon N, Cannizzaro C, Chao PHG, Maidhof R, Marsano A, Au HTH, Radisic M, Vunjak-Novakovic G. 2009. Elec- trical stimulation systems for cardiac tissue engineering. Nat Protoc 4: 155-173.

Tandon N, Marsano A, Maidhof R, Wan L, Park H, VunjakNovakovic G. 2011. Optimization of electrical stimulation parameters for cardiac tissue engineering. J Tissue Eng Regen Med 5: e115-e125.

Tara S, Kurobe H, Rocco KA, Maxfield MW, Best CA, Yi T, Naito Y, Breuer CK, Shinoka T. 2014. Well-organized neointima of large-pore poly(L-lactic acid) vascular graft coated with poly(L-lactic-co- $\varepsilon$-caprolactone) prevents calcific deposition compared to small-pore electrospun poly(L-lactic acid) graft in a mouse aortic implantation model. Atherosclerosis 237: 684-691.

Tavakkol Z, Gelehrter S, Goldberg CS, Bove EL, Devaney EJ, Ohye RG. 2005. Superior durability of SynerGraft pulmonary allografts compared with standard cryopreserved allografts. Ann Thorac Surg 80: 1610-1614.

Tiburcy M, Didié M, Boy O, Christalla P, Döker S, Naito H, Karikkineth BC, El-Armouche A, Grimm M, Nose M, et al. 2011. Terminal differentiation, advanced organotypic maturation, and modeling of hypertrophic growth in engineered heart tissue. Circ Res 109: 1105-1114.

Toma C, Pittenger MF, Cahill KS, Byrne BJ, Kessler PD. 2002. Human mesenchymal stem cells differentiate to a cardiomyocyte phenotype in the adult murine heart. Circulation 105: 93-98.

Tulloch NL, Muskheli V, Razumova M V, Korte FS, Regnier M, Hauch KD, Pabon L, Reinecke H, Murry CE. 2011. Growth of engineered human myocardium with mechanical loading and vascular coculture. Circ Res 109: $47-59$.

Vunjak-Novakovic G, Lui KO, Tandon N, Chien KR. 2011. Bioengineering heart muscle: A paradigm for regenerative medicine. Annu Rev Biomed Eng 13: 245-267.

Wang Z, Cui Y, Wang J, Yang X, Wu Y, Wang K, Gao X, Li D, Li Y, Zheng XL, et al. 2014. The effect of thick fibers and large pores of electrospun poly $(\varepsilon$-caprolactone) vascular grafts on macrophage polarization and arterial regeneration. Biomaterials 35: 5700-5710.

Weber B, Emmert MY, Behr L, Schoenauer R, Brokopp C, Drögemüller C, Modregger P, Stampanoni M, Vats D, Rudin M, et al. 2012. Prenatally engineered autologous amniotic fluid stem cell-based heart valves in the fetal circulation. Biomaterials 33: 4031-4043.

Weber B, Dijkman PE, Scherman J, Sanders B, Emmert MY, Grünenfelder J, Verbeek R, Bracher M, Black M, Franz T, et al. 2013. Off-the-shelf human decellularized tissue-engineered heart valves in a non-human primate model. Biomaterials 34: 7269-7280.

Wilson GJ, Courtman DW, Klement P, Michael Lee J, Yeger H. 1995. Acellular matrix: A biomaterials approach for coronary artery bypass and heart valve replacement. Ann Thorac Surg 60: S353-S358.

Woo JS, Fishbein MC, Reemtsen B. 2015. Histologic examination of decellularized porcine intestinal submucosa extracellular matrix (CorMatrix) in pediatric congenital heart surgery. Cardiovasc Pathol 25: 12-17.

Wystrychowski W, McAllister TN, Zagalski K, Dusserre N, Cierpka L, L'Heureux N. 2014. First human use of an allogeneic tissue-engineered vascular graft for hemodialysis access. J Vasc Surg 60: 1353-1357. 
Yanagawa B, Rao V, Yau TM, Cusimano RJ. 2014. Potential myocardial regeneration with CorMatrix ECM: A case report. J Thorac Cardiovasc Surg 147: e41-e43.

Yang L, Soonpaa MH, Adler ED, Roepke TK, Kattman SJ, Kennedy M, Henckaerts E, Bonham K, Abbott GW, Linden RM, et al. 2008. Human cardiovascular progenitor cells develop from a $\mathrm{KDR}^{+}$embryonic-stem-cell-derived population. Nature 453: 524-528.

Yao L, Swartz DD, Gugino SF, Russell JA, Andreadis ST. 2005. Fibrin-based tissue-engineered blood vessels: Differential effects of biomaterial and culture parameters on mechanical strength and vascular reactivity. Tissue Eng 11: 9911003.
Zhang J, Wilson GF, Soerens AG, Koonce CH, Yu J, Palecek SP, Thomson JA, Kamp TJ. 2009. Functional cardiomyocytes derived from human induced pluripotent stem cells. Circ Res 104: e30-e41.

Zhang T, Wan LQ, Xiong Z, Marsano A, Maidhof R, Park M, Yan Y, Vunjak-Novakovic G. 2012. Channelled scaffolds for engineering myocardium with mechanical stimulation. J Tissue Eng Regen Med 6: 748-756.

Zimmermann WH, Melnychenko I, Wasmeier G, Didié M, Naito H, Nixdorff U, Hess A, Budinsky L, Brune K, Michaelis B, et al. 2006. Engineered heart tissue grafts improve systolic and diastolic function in infarcted rat hearts. Nat Med 12: 452-458. 


\section{$\&_{\mathrm{CSH}}^{\infty} \&$ Cold Spring Harbor

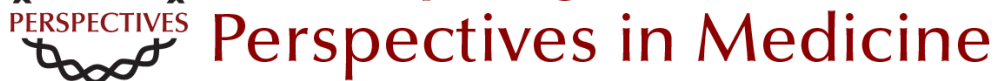

\section{The Heart and Great Vessels}

Ekene Onwuka, Nakesha King, Eric Heuer and Christopher Breuer

Cold Spring Harb Perspect Med 2018; doi: 10.1101/cshperspect.a031922 originally published online March 13, 2017

Subject Collection Tissue Engineering and Regenerative Medicine

The Heart and Great Vessels

Ekene Onwuka, Nakesha King, Eric Heuer, et al.

Three-Dimensional Bioprinting Strategies for

Tissue Engineering

Yu Shrike Zhang, Rahmi Oklu, Mehmet Remzi

Dokmeci, et al.

Honing Cell and Tissue Culture Conditions for

Bone and Cartilage Tissue Engineering Johnny Lam, Esther J. Lee, Elisa C. Clark, et al.

Tissue Engineering Functional Gastrointestinal Regions: The Importance of Stem and Progenitor Cells

Andrew Trecartin and Tracy Grikscheit

\section{Historical Perspective and Future Direction of Blood Vessel Developments Sashka Dimitrievska and Laura E. Niklason \\ Craniofacial Tissue Engineering \\ Weibo Zhang and Pamela Crotty Yelick}

The Self-Assembling Process and Applications in Tissue Engineering Jennifer K. Lee, Jarrett M. Link, Jerry C.Y. Hu, et al.

Biologic Scaffolds

Alessandra Costa, Juan Diego Naranjo, Ricardo Londono, et al.

For additional articles in this collection, see http://perspectivesinmedicine.cshlp.org/cgi/collection/ 